\title{
Development of combinatorial abilities of students in the process of developing compositions of mathematical problems
}

\author{
Aleksander Savenkov ${ }^{1 *}$, Marina Romanova ${ }^{1}$, and Lkhamtseren Bold ${ }^{2}$ \\ ${ }^{1}$ Moscow City University, Institute of Pedagogy and Psychology of Education, Moscow, Russia \\ ${ }^{2}$ Mongolian Institute for Educational Research (MIER), Sector of Higher and Vocational Educational \\ Research, Ulaanbaatar, Mongolia
}

\begin{abstract}
Well-developed combinatorial abilities are an essential component of the professionalism of a modern primary school teacher. The goal of the present study is to search for methodological techniques for lessons on the methods of teaching mathematics in primary school that would activate the interconnection of logical thinking and several noncognitive abilities of teachers in training. Said interconnection is viewed as a means allowing diagnosing and developing the combinatorial abilities of future primary school teachers. The study implements testing methods with consecutive mathematical processing. Assessment of the non-cognitive factors (the level of general cultural development, general humanitarian training, characteristics of the microenvironment, the level of general psychosocial development, etc.) involved the methods assessing academic success and psychosocial development level, as well as expert assessment of the level of general cultural development. These data were compared with the level of development of pedagogical university students' logical thinking determined through Raven's Progressive Matrices. The forming stage of the study involved original methodological techniques used to stimulate university students' interest in creating compositions of textual mathematical problems for primary school students. The proposed methodological solutions to the problems of the diagnostics and development of combinatorial thinking in future teachers understood as a combination of logical thinking and several non-cognitive factors have shown themselves to be effective. The development of compositions of textual mathematical problems for primary school students is an effective means of developing future teachers' combinatorial abilities. Keywords: combinatorial thinking, non-cognitive factors, mathematics teaching methods, primary school teachers, primary school students.
\end{abstract}

\section{Introduction}

The topic of development of combinatorial abilities as a necessary component of the professionalism of a modern primary school teacher increasingly often presents the interest of Russian and foreign researchers studying the relationship between emotional intelligence

${ }^{*}$ Corresponding author: asavenkov@,bk.ru 
and cognitive abilities [1], cognitive foundations of scientific literacy [2], the relationship between intellect and academic achievements [3], and the general deep structures of early mathematical literacy [4-9]. The issues of the creativity of didactic materials and the effect of the choice of a mathematics textbook on the performance of primary school students are also becoming the subject of scientific and methodological research $[10,11]$.

Examining the main factors in the development of the intellectual and creative potential of personality $[12,13,15]$ and the implementation of interactive methods in the university educational process [14], researchers stress that the productivity of thinking in solving divergent problems presents an important indicator of the development of combinatorial abilities as it allows achieving original results through the means of analysis, comparison, and combination of a large number of options. Since combinatorial thinking is viewed as a combination of logical thinking and several non-cognitive factors, we proceeded from the assumption that the most effective way of its development will be to focus on their development in future teachers.

\section{Methods}

The study sample comprised 46 bachelor students of the Moscow City University studying in the "primary education" training profile.

The criteria for the assessment of non-cognitive factors were compared with the level of development of the students' logical thinking. The assessment of non-cognitive factors involved the expert assessment method while general cognitive abilities, primarily the logical thinking ability, were measured using Raven's Progressive Matrices.

The conducted experiment involved methodological problems requiring independent thinking, originality, ingenuity, and a high degree of novelty of the proposed solution. The study demonstrated that the process of development of combinatorial abilities in future teachers is much more complex than the process of them mastering the basic content of the primary mathematics course and the development of their theoretical thinking. The issue was resolved by presenting students with problems directly requiring the deployment of combinatorial thinking abilities. These problems were integrative and included materials from the studied pedagogical and psychological academic disciplines.

The practice demonstrated that the greatest effect was produced by educational problems requiring the students to develop mathematical problem compositions themselves. The students were constructing the texts of typical and increased complexity problems, as well as complex mathematical problems in the PISSA format.

In creating the problems, the students were coming into contact with the internal structure of the text they had been creating and were directly implementing the elements associated with the development of combinatorial abilities:

- knowledge of the exact definitions of mathematical concepts, the ability to present one's own alternative definitions;

- knowledge and ability to analyze the definitions of scientific mathematical concepts in terms of them observing the rules of logic;

- knowledge and skillful use of well-known mathematical propositions in proving other mathematical statements and searching for solutions to various mathematical problems;

- ability to think logically, reason, and solve the same mathematical problems in different ways;

- $\quad$ ability to prove the same mathematical statements in different ways;

- ability to find and correct errors in mathematical proofs and reasoning;

- $\quad$ ability to apply mathematical knowledge in solving practical problems;

- ability to explain the same educational material in mathematics to children clearly and understandably in different ways. 
Below we present the examples of the texts of problems constructed by the university students.

"Second-graders are filming a cartoon called "Joyful mice". For the movements of mice to seem even and continuous, each second of the film should fit 25 frames. How many frames will second-graders have to make for a 4-minute long cartoon?"

"In three years, the music band "Grumpy" released 15 songs with the same number of songs being released every year. Its competitors, the band "Turtles", released three songs more per year than "Grumpy". How many songs are in Vitia's playlist if he downloaded all songs of both bands?"

"Anton and Natasha decided that a robot should do their homework assignments for them. They uploaded the contents of their school bags to their computer. Instead of answers, the computer produced a broken line of three links. The length of the first link is 1 decimeter, the second one is 3 centimeters shorter, and the third one is 5 centimeters longer than the second one. How long was the broken line the children got instead of completed homework?"

The evidence of the developed combinatorial thinking of the students is that the text itself and the methods for solving the designed problems were created based on the versatility and variety of plotlines for the production of compositions, on the one hand, and the restrictions due to the features of the content of the elementary mathematics course, on the other.

\section{Discussion}

The goal of the empirical stage of the study is to determine the relationship and mutual influence of the levels of development of combinatorial abilities, general cognitive development, and non-cognitive factors. Correlation analysis and analysis of variance were used to study the relationship and interaction of the scales. Correlation analysis data are presented in Table 1.

Table 1. Empirical values of correlation analysis.

\begin{tabular}{|l|c|c|c|c|}
\hline \multicolumn{1}{|c|}{ Criteria } & $\begin{array}{c}\text { General } \\
\text { humanitaria } \\
\text { n training }\end{array}$ & $\begin{array}{c}\text { Combinatori } \\
\text { al abilities }\end{array}$ & $\begin{array}{c}\text { Psychosocial } \\
\text { development }\end{array}$ & Outlook \\
\hline Logical thinking ability & $0.842^{* * *}$ & $0.922^{* * *}$ & $0.839^{* * *}$ & $0.872^{* * *}$ \\
\hline $\begin{array}{l}\text { General humanitarian } \\
\text { training }\end{array}$ & & $0.704^{* * *}$ & $0.799^{* * *}$ & $0.823^{* * *}$ \\
\hline Psychosocial development & & & & $0.963^{* * *}$ \\
\hline Combinatorial abilities & & & $0.734^{* * *}$ & $0.769^{* * *}$ \\
\hline
\end{tabular}

It was established that the increase in the "General humanitarian training" scale determines the growth of values in the "Combinatorial abilities" scale. The obtained value $\mathrm{r}=0.704(\mathrm{p}<0.001)$ indicates the presence of a significant strong positive correlation between the "General humanitarian training" and "Combinatorial abilities" scales.

The rise of indicators in the "Logical thinking ability" scale also ensures an upward tendency in the "Combinatorial abilities" scale indicators. The obtained correlation coefficient demonstrates significant strong positive relations between the "Combinatorial abilities" scale and the factor of "Logical thinking ability" $(\mathrm{r}=0.922, \mathrm{p}<0.001)$.

A strong significant positive correlation is observed between the "Combinatorial abilities" and "Psychosocial development" scales $(\mathrm{r}=0.734, \mathrm{p}<0.001)$. The respondents with high scores in the indicators of the "Psychosocial development" scale also had higher indicators on the "Combinatorial abilities" scale. 
A strong significant positive relationship is also detected between the "Combinatorial abilities" and "Outlook" scales $(r=0.769, \mathrm{p}<0.001)$. High indicators in the "Outlook" scale correlate with analogical results in the "Combinatorial abilities" scale.

The conducted analysis of variance of the obtained data allows us to state that noncognitive factors directly affect the development of future teachers' combinatorial abilities. Leven's test was used to confirm the formulated conclusion and statistically significant effects of the selected non-cognitive factors were discovered. The degree of influence of each factor is examined below.

Table 2. Assessment of the effect of general humanitarian training on combinatorial abilities.

\begin{tabular}{|c|c|c|c|c|c|c|c|}
\hline \multicolumn{4}{|c|}{$\begin{array}{l}\text { Descriptive statistics for the "Combinatorial } \\
\text { abilities" scale }\end{array}$} & \multirow[b]{2}{*}{$\begin{array}{l}\text { Levene } \\
\text { statistics }\end{array}$} & \multirow[b]{2}{*}{$\begin{array}{l}\text { Levene's test } \\
\text { significance } \\
\text { level }\end{array}$} & \multirow[b]{2}{*}{ F-value } & \multirow[b]{2}{*}{$\begin{array}{c}\text { F-value } \\
\text { significance } \\
\text { level }\end{array}$} \\
\hline \begin{tabular}{|c|} 
with 2 \\
points of \\
the \\
parameter
\end{tabular} & \begin{tabular}{|c|} 
with 3 \\
points of \\
the \\
parameter
\end{tabular} & $\begin{array}{l}\text { with } 4 \\
\text { points of } \\
\text { the } \\
\text { parameter }\end{array}$ & \begin{tabular}{|c|} 
with 5 \\
points of \\
the \\
parameter
\end{tabular} & & & & \\
\hline $44.6 \pm 4.0$ & $51.3 \pm 1.8$ & $53.9 \pm 1.7$ & $57.1 \pm 1.3$ & 2.957 & $0.051^{*}$ & 32.294 & $0.001 * * *$ \\
\hline
\end{tabular}

Using One-Way ANOVA was sufficient to evaluate the effect of general humanitarian training on combinatorial abilities as no statistically significant differences between the variances were found $(\mathrm{F}=2.957 ; \mathrm{p}>0.05)$. However, a statistically reliable impact of the "General humanitarian training" variable on the values of the "Combinatorial abilities" scale was established $(\mathrm{F}=32.294 ; \mathrm{p}<0.001)$. The highest value is observed at 5 points of the parameter $(7.1 \pm 1.3)$ and the lowest values appear at 2 points $(44.6 \pm 4.0)$.

Table 3. The effect of outlook on combinatorial abilities.

\begin{tabular}{|c|c|c|c|c|c|c|}
\hline \multicolumn{3}{|c|}{$\begin{array}{l}\text { Descriptive statistics for the } \\
\text { "Combinatorial abilities" scale }\end{array}$} & \multirow[b]{2}{*}{$\begin{array}{c}\text { Levene } \\
\text { statistics }\end{array}$} & \multirow{2}{*}{$\begin{array}{c}\text { Levene's } \\
\text { test } \\
\text { significanc } \\
\text { e level }\end{array}$} & \multirow[b]{2}{*}{$\begin{array}{c}\text { Welch's } \\
\text { t-test }\end{array}$} & \multirow[b]{2}{*}{$\begin{array}{c}\text { F-value } \\
\text { significanc } \\
\text { e level }\end{array}$} \\
\hline $\begin{array}{l}\text { with the low } \\
\text { level of the } \\
\text { parameter }\end{array}$ & $\begin{array}{c}\text { with the } \\
\text { average level } \\
\text { of the } \\
\text { parameter }\end{array}$ & $\begin{array}{l}\text { with the high } \\
\text { level of the } \\
\text { parameter }\end{array}$ & & & & \\
\hline $46.5 \pm 4.9$ & $52.9 \pm 2.1$ & $57.5 \pm 0.5$ & 3.708 & 0.038 & 7.126 & $0.001 * * *$ \\
\hline
\end{tabular}

Levene's test demonstrates statistically significant differences between the variances $(\mathrm{F}=3,708 ; \mathrm{p}<0,05)$. Therefore, One-Way ANOVA has to be applied using Welch's test. The analysis demonstrated a statistically significant effect of the "Outlook" variable on the values of the "Combinatorial abilities" scale $(\mathrm{F}=7.126 ; \mathrm{p}<0.001)$. The highest values are observed at a high level of the examined parameter $(57.5 \pm 0.5)$ and the lowest values appear at the low level $(46.5 \pm 4.9)$.

Table 4. The effect of psychosocial development on combinatorial abilities.

\begin{tabular}{|c|c|c|c|c|c|c|}
\hline \multicolumn{3}{|c|}{$\begin{array}{c}\text { Descriptive statistics for the "Combinatorial } \\
\text { abilities" scale }\end{array}$} & \multirow[b]{2}{*}{$\begin{array}{l}\text { Levene } \\
\text { statistics }\end{array}$} & \multirow{2}{*}{$\begin{array}{c}\text { Levene's } \\
\text { test } \\
\text { significan } \\
\text { ce level }\end{array}$} & \multirow[b]{2}{*}{$\begin{array}{c}\text { Welch's } \\
\text { t-test }\end{array}$} & \multirow[b]{2}{*}{$\begin{array}{c}\text { F-value } \\
\text { significance } \\
\text { level }\end{array}$} \\
\hline $\begin{array}{l}\text { with the low } \\
\text { level of the } \\
\text { parameter }\end{array}$ & $\begin{array}{c}\text { with the } \\
\text { average level } \\
\text { of the } \\
\text { parameter }\end{array}$ & $\begin{array}{l}\text { with the high } \\
\text { level of the } \\
\text { parameter }\end{array}$ & & & & \\
\hline $46.5 \pm 4.9$ & $52.9 \pm 2.1$ & $57.5 \pm 0.5$ & 3.708 & 0.038 & 7.126 & $0.001 * * *$ \\
\hline
\end{tabular}

Levene's test demonstrates statistically significant differences between the variances $(\mathrm{F}=3,708 ; \mathrm{p}<0,05)$. Therefore, One-Way ANOVA has to be applied using Welch's test. The analysis demonstrated a statistically significant effect of the "Outlook" variable on the values of the "Combinatorial abilities" scale $(\mathrm{F}=7.126$; $\mathrm{p}<0.001)$. The highest values are 
observed at a high level of the examined parameter $(57.5 \pm 0.5)$ and the lowest values appear at the low level $(46.5 \pm 4.9)$.

Table 5. The effect of the level of development of logical thinking abilities on combinatorial abilities.

\begin{tabular}{|c|c|c|c|c|c|c|}
\hline \multicolumn{3}{|c|}{$\begin{array}{l}\text { Descriptive statistics for the } \\
\text { "Combinatorial abilities" scale }\end{array}$} & \multirow[b]{2}{*}{$\begin{array}{c}\text { Levene } \\
\text { statistics }\end{array}$} & \multirow[b]{2}{*}{$\begin{array}{l}\text { Levene's } \\
\text { test } \\
\text { significanc } \\
\text { e level }\end{array}$} & \multirow[b]{2}{*}{ F-value } & \multirow[b]{2}{*}{$\begin{array}{c}\text { F-value } \\
\text { significance } \\
\text { level }\end{array}$} \\
\hline $\begin{array}{c}\text { with } 3 \\
\text { points of } \\
\text { the } \\
\text { parameter }\end{array}$ & $\begin{array}{l}\text { with } 4 \text { points } \\
\text { of the } \\
\text { parameter }\end{array}$ & $\begin{array}{c}\text { with } 5 \\
\text { points of } \\
\text { the } \\
\text { parameter }\end{array}$ & & & & \\
\hline $46.5 \pm 4.9$ & $51.6 \pm 1.8$ & $56.0 \pm 1.6$ & 3.117 & $0.061^{*}$ & 30.806 & $0.001 * * *$ \\
\hline
\end{tabular}

Due to the absence of statistically significant differences between variances according to Levene's test $(\mathrm{F}=3.117 ; \mathrm{p}>0.05)$, the degree of influence of the level of logical thinking abilities on combinatorial abilities was tested using One-Way ANOVA. The analysis showed a statistically significant effect of the "Theoretical basics of the primary mathematics course" variable on values of the "Combinatorial abilities" scale ( $F=30.806$; $\mathrm{p}<0.001)$. The greater values are observed at the 5-point level of the examined parameter $(56.0 \pm 1.6)$ and the lowest values are detected at the 3-point level (46.5 \pm 4.9$)$.

\section{Conclusion}

The proposed methodological solution to the problem of the development of combinatorial thinking in future teachers viewed as a combination of logical thinking and several noncognitive factors was proven to be effective. Composing mathematical problems for primary school students requires the activation of cognitive abilities and psychosocial development levels of pedagogical university students. Thus, the development of compositions of mathematical problems for primary school children presents an effective instrument for the development of future teachers' combinatorial abilities.

\section{References}

1. S. Agnoli, G. Mancini, T. Pozzoli, B. Baldaro, P.M. Russo, P. Surcinelli, Personality and Individual Differences, 53(5), 660-665 (2012).

https://doi.org/10.1016/j.paid.2012.05.020

2. J.-R. Bauer, A.E. Booth, Early Childhood Research Quarterly, 46, 275-284 (2019). https://doi.org/10.1016/j.ecresq.2018.09.007

3. I.J. Deary, S. Strand, P. Smith, C. Fernandes, Intelligence, 35(1), 13-21 (2007). https://doi.org/10.1016/j.intell.2006.02.001

4. M. Burchinal et. al., Early Childhood Research Quarterly, 51, 67-80 (2020). https://doi.org/10.1016/j.ecresq.2019.08.004

5. W.W.L. Chan, T.T.-Y. Wong, Learning and Instruction, 62, 11-19 (2019). https://doi.org/10.1016/j.learninstruc.2019.03.001

6. M.A. Collins, E.V. Laski, Early Childhood Research Quarterly, 46, 201-212 (2019). https://doi.org/10.1016/j.ecresq.2018.02.008

7. A. Demetriou et. al., Cognitive Development, 54, 100872 (2020). https://doi.org/10.1016/j.cogdev.2020.100872 
8. T. Tikhomirova, E. Khusnutdinova, S. Malykh, Sibirskii Psikhologicheskii Zhurnal, 73, 159-175 (2019)

9. T. N. Tikhomirova et. al., Psikhologicheskii Zhurnal, 36(5), 43-54 (2015)

10. A. Gajda, M. Karwowski, R.A. Beghetto, Journal of Educational Psychology, 109(2), 269-299 (2017). https://doi.org/10.1037/edu0000133

11. A.-K. van den Ham, A. Heinze, Studies in Educational Evaluation, 59, 133-140 (2018). https://doi.org/10.1016/j.stueduc.2018.07.005

12. A. I. Savenkov, M. A. Romanova, Tambov University Review. Series: Humanities, 7(75), 234-238 (2009)

13. A. Savenkov, S. I. Karpova, E. I. Sukhova, Psychology (Savannah, Ga.), 55(2), 74-84 (2018)

14. R. A. Kutbiddinova, A. A. Eromasova, M. A. Romanova, International Journal of Environmental and Science Education, 11(14), 6557-6572 (2016)

15. D.J. Purpura, S. A. Schmitt, Early Childhood Research Quarterly, 46, 1-4 (2019). https://doi.org/10.1016/j.ecresq.2018.10.009 